\title{
Servikal ektopik gebelik: Olgu sunumu
}

\section{Cervikal ectopic pregnancy: A case report}

\author{
Çiğdem Kunt İşgüder, ${ }^{1}$ Hatice Yılmaz Doğru, ${ }^{1}$ Selim Gülücü, ${ }^{1}$ Asker Zeki Özsoy,, ${ }^{1}$ Nurşah Başol ${ }^{2}$ \\ 'Gaziosmanpaşa Üniversitesi Tıp Fakültesi, Kadın Hastalıkları ve Doğum Anabilim Dalı, Tokat, Turkey \\ ${ }^{2}$ Gaziosmanpaşa Üniversitesi Tıp Fakültesi, Acil Tıp Anabilim Dalı, Tokat, Turkey
}

\section{Özet}

Servikal ektopik gebelik, blastokistin endoservikal bölgeye implante olması sonucu ortaya çıkan nadir bir durumdur. Servikal gebeliğin erken tanınması ve tedavisi hayat kurtarıcı olduğu kadar fertilitenin korunması açısından da önemlidir. Bu olguda fertilite korunarak, konservatif tedavi yöntemi olan sistemik MTX tedavisi esnasında gelişen vajinal kanamayı durdurmak için invaziv girişimler yapılmadan servikal küretaj ile etkin bir şekilde kontrol altına alınan servikal ektopik gebelik olgusu literatür eşliğinde sunulmuştur.

Anahtar Sözcükler: Servikal ektopik gebelik; tanı; tedavi.

$E_{r}^{k}$ ktopik gebelik, tüm gebeliklerin yaklaşık \%1-2'sinde görülen ve gebelik ürününün uterin kavite dışında başka bir yere implante olması olarak tanımlanan bir hastalıktır. En sık karşılaşılan tip tubal gebelik (\%95) olmakla beraber, nadir görülen bir tipi de servikal gebeliktir. Tüm ektopik gebeliklerin \%0.1-0.2'sini oluşturan servikal gebeliğin insidansı 10000 gebelikte birdir. ${ }^{[1-3]}$ Servikal gebelik, blastokistin anormal olarak internal servikal os seviyesi altında endoservikal kanala implantasyonu sonucu oluşur. Masif kanamaya neden olabilmesi açısından maternal mortalite ve morbiditenin önemli nedenleri arasında yer almaktadır. Servikal gebeliğin erken tanınması ve tedavisi hayat kurtarıcı olduğu kadar fertilitenin korunması açısından da önemlidir. Konservatif tedavide sistemik metotreksat (MTX) veya intra-amniyotik potasyum klorid $(\mathrm{KCl})$ uygulanmakta fakat bu konservatif tedaviler işlem esnasında hayatı tehdit eden aşırı kanamalara neden olabilmektedir. ${ }^{[4]} \mathrm{Bu}$ olguda, sistemik MTX tedavisi sonrasında servikal küretaj ile başarılı bir şekilde tedavi edilen bir servikal gebelik vakası literatür eşliğinde sunularak konuya dikkat çekmek amaçlanmıştır.

\begin{abstract}
Cervical ectopic pregnancy which blastocyste implants in the endocervical region is a rare form of ectopic pregnancy. Early diagnosis and treatment are very important due to prevention of mortality and preserving fertility. In this case, vaginal bleeding while receiving MTX was treated by cervical curettage instead of invasive procedures and this approach resulted in the preservation of fertility. This report reviews cervical ectopic pregnancy within the scope of current literature.
\end{abstract}

Keywords: Cervical ectopic pregnancy; diagnosis; treatment.

\section{Olgu Sunumu}

On dokuz yaşındaki hasta, dış merkezde ektopik gebelik ön tanısı alarak, nullipar olması göz önünde bulundurulup hastanemize sevk edildi. Obstetrik hikayesinde hastanın servikal ektopik gebelik için jinekolojik ya da cerrahi risk faktörü bulunmadığı, herhangi bir infertilite tedavisi almadığı ve planlanmış spontan ilk gebeliği olduğu öğrenildi. Son adet tarihine göre 6 hafta 5 günlük gebeliği mevcuttu. Olgunun adet gecikmesi dışında vaginal kanama, kasık ağrısı ve alt abdomen hassasiyeti gibi ek bir şikayeti yoktu. Fizik muayenede Tansiyon/ Arteriyel: 90/60 mmHg, nabız: 76 /dakika, batın normal bombelikte idi, defans ve rebound yoktu. Jinekolojik muayenede vulva ve vajina doğaldı, serviks nullipar vasıftaydı ve kanama izlenmemekteydi. Transvaginal ultrasonografide (TVUSG) uterin kavite boştu, endometrium çift duvar kalınlığı $7 \mathrm{~mm}$ olarak ölçüldü, internal servikal os seviyesinin altında, serviks arka duvarına invaze halde $20 \times 10 \mathrm{~mm}$ boyutlarında gestasyonel kese ve bu kesenin içinde yolk sac ile birlikte kalp atımı olmayan bie embriyo izlendi (Şekil 1a-c). Beta-human koryonik 

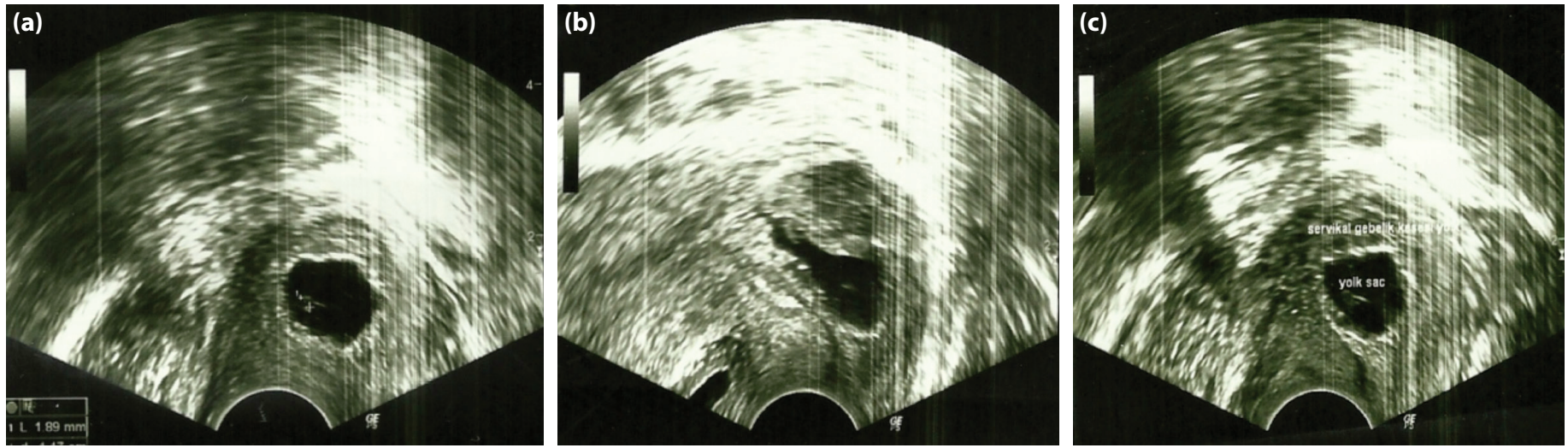

Şekil 1. (a)TVUSG'de 20x10 mm'lik servikal gestasyonel kese görünümü. (b) TVUSG'de serviks arka duvarda invaze gestasyonel kese görünümü. (c) TVUSG'de servikal gestasyonel kese içinde embriyo ve yolksack görünümü.

gonodotropin ( $\beta \mathrm{hCG}$ ) seviyesi $3410 \mathrm{mlU} / \mathrm{ml}$ olan hastaya tek doz sistemik MTX $\left(50 \mathrm{mgr} / \mathrm{m}^{2}\right)^{\prime}$ In intra-muskuler olarak uygulanmasına karar verildi. Kan grubu: 0 Rh (+), tam sayımı ile birlikte karaciğer ve böbrek fonksiyon testleri, MTX tedavisinden önce ve tedavi sırasında normal aralıktaydı. MTX tedavisinin 7. gününde servikal gebelik materyali abort oldu. Serum $\beta$ hCG seviyesi $359 \mathrm{mIU} / \mathrm{ml}$ olan ve vaginal kanaması ola hastaya servikal küretaj yapıldı. Tedaviden önceki serum $\beta$ hCG seviyesine göre \%15'ten fazla bir düşme olduğu için 2. doz MTX uygulanmadı. Bir gün sonra serum $\beta$ hCG düzeyi $271 \mathrm{mlU} / \mathrm{ml}$ olarak ölçülen, TVUSG bulguları normal olan ve kanaması kesilen hasta taburcu edildi. Histopatolojik inceleme sonucu hemorajik ve iskemik değişiklikler izlenen abort materyali olarak rapor edildi. Birinci ay sonundaki kontrolde $\beta$ hCG değeri negatif olarak saptanan hastanın jinekolojik muayenesi ve TVUSG incelemesi normaldi.

\section{Tartışma}

Servikal gebeliğin tanısı diğer ektopik gebeliklere göre daha zor konulduğundan tedavide gecikmeler olabilir. Bu gecikmiş müdahale sıklıkla masif kanamaya yol açıp, olguların yaklaşık \%50'sinde acil histerektomi yapılmasına yol açabilir. ${ }^{[5]}$ Endometrial hasar, servikal gebeliğin etyolojisindeki en önemli faktördür. Geçirilmiş intrauterin müdahalelerin endometriumda oluşturduğu bu hasara bağlı olarak endometrial implantasyonun engellendiği düşünülmektedir. Endometrial hasar için risk faktörleri; geçirilmiş dilatasyon küretaj ve diğer uterin cerrahiler, sezaryen ile doğum, abortus öyküsü, RİA, submukoz myom ve kronik endometrit, Asherman sendromu, terapötik abort ve ektopik gebelik öyküsüdür. Ayrıca kromozomal anomalili embryo ve üremeye yardımcı tekniklerin kullanımı ile servikal gebelik arasında bir ilişki tespit edilmiştir. ${ }^{[2,6,7]}$ Servikal gebeliğin en sık görülen semptomu vajinal kanama (\%91) ve kasık ağrısı (\%28) olarak belirtilse de sunulan olguda bu sık görülen semptomlar mevcut değildi. Bunun yanında jinekolojik ya da cerrahi herhangi bir risk faktörü de yoktu. ${ }^{[2]}$

Servikal gebelik tanısında klinik bulguların yanı sıra, $\beta$ hCG ölçümünden, ultrasonografi (USG), ve magnetik rezonans görüntülemeden (MRG) yararlanılır. USG'de gebelik kesesinin servikste görülmesi, servikal duvara trofoblastik invazyonun olması ve uterus boyutlarının normal olması ile tanı konulur. [2] Servikal gebelik tanısında MRI, USG'nin kısıtlı olduğu durumlarda kullanılabilir fakat acil durumlarda hemen el altında olmaması dezavantajıdır. ${ }^{[8]}$ Bizim olgumuzda tanı saptanan pozitif $\beta$ hCG sonrasında yapılan TVUSG ile konuldu. TVUSG'de gestasyonel kesenin servikal kanalda, serviks arka duvarına invaze olduğu izlenirken, uterin kavitede ise gebelik ürünü izlenmedi.

Servikal gebeliğin yönetiminde tıbbi ve/veya cerrahi tedavi uygulanabilir. Tedavi seçiminde kanamanın miktarı, gestasyonel yaş, gestasyonel kesenin lokalizasyonu, trofoblast invazyonunun derinliği, $\beta$ hCG değeri ve fertilite isteğinin olup olmaması etkilidir. Fertilitesini tamamlamamış kadınlarda servikal gebelikte tıbbi tedavi olarak MTX'ın sistemik ya da intra-amniotik uygulanması tercih edilmelidir. ${ }^{[9,10]}$ Sistemik MTX tek doz veya çoklu dozlar halinde uygulanabilir. İleri gestasyonel yaş, yüksek serum $\beta$ hCG seviyesi, fetal kardiyak aktivitenin varlığında tıbbi tedavideki başarısızlık oranı yüksektir. Böyle durumlarda sistemik MTX ile birlikte fetal intrakardiyak $\mathrm{KCl}$ uygulanabilir. [11] Servikal ektopik gebeliklerde MTX ile tıbbi tedavi esnasında şiddetli uterin kanamalar meydana gelebilir. ${ }^{[12]}$ Böyle bir durum; servikal küretaj, küretaj sonrasında intraservikal foley sonda uygulaması ve servikal sütür ile kontrol altına alınabilir. ${ }^{[13,14]}$ Tıbbi tedavi sonrası vajinal kanama görülürse ve fertilitenin korunması isteniyorsa, selektif uterin arter embolizasyonu uygulanarak etkin kanama kontrolü sağlanabilir. ${ }^{[15,16]}$ Kanamanın kontrol altına alınamadığı durumlarda internal iliak arter ligasyonu, vaginal ya da abdominal histerektomi gibi radikal tedaviler uygulanabilir. ${ }^{[17-19]}$ Sunulan bu olguda, MTX tedavisi sonrası kanama kontrolü için küretaj yapılmış ve kanama kontrolü sağlandığı için arter embolizasyonu veya histerektomi gibi daha invaziv girişimlere gerek kalmamıştır.

\section{Sonuç}

Sonuç olarak servikal gebelik, erken tanınması gereken ektopik gebeliğin nadir bir şeklidir. Konservatif tedavi yöntemi 
olan sistemik MTX tedavisi esnasında gelişen vajinal kanama daha invaziv girişimlere gerek kalmadan ve fertilite korunarak servikal küretaj ile etkin bir şekilde kontrol altına alınabilmektedir.

Çıkar çatışması: Bildirilmemiştir.

\section{Kaynaklar}

1. Breen JL. A 21 year survey of 654 ectopic pregnancies. Am J ObstetGynecol 2002;106:1004-19.

2. Ushakov FB, Elchalal U, Aceman PJ, Schenker JG. Cervical pregnancy: past and future. Obstet Gynecol Surv 1997;52:45-59.

3. Vela G, Tulandi T. Cervical pregnancy: the importance of early diagnosis and treatment. J Minim Invasive Gynecol 2007;14:481-4.

4. Frates MC, Benson CB, Doubilet PM. Cervical ectopic pregnancy: results of conservative treatment. Radiology 1994;19:773-5.

5. Yitzhak M1, Orvieto R, Nitke S, Neuman-Levin M, Ben-Rafael Z, Schoenfeld A. Cervical pregnancy a conservative stepwise approach. Hum Reprod 1999;14: 847-9.

6. Jeng $\mathrm{CJ}$, Ko ML, Shen J. Transvaginal ultrasound-guided treatment of cervical pregnancy. Obstet Gynecol 2007;109:1076-82.

7. Ginsburg ES, Frates MC, Rein MS, Fox JH, Hornstein MD, Friedman AJ. Friedman AJ. Early diagnosis and treatment of cervical pregnancy in an in vitro fertilization program. Fertil Steril 1994;61:966-9.

8. Jung SE, Byun JY, Lee JM, Choi BG, Hahn ST. Characteristic MR findings of cervical pregnancy. J MagnReson Imaging 2001;13:91822.
9. Sherer DM, Dalloul M, Santoso P, Stimphil R, Sokolovski M, Abulafia O. Complete abortion of a nonviable cervical pregnancy following methotrexate treatment. Am J Perinatol 2004;21:223-6.

10. Kirk E, Condous G, Haider Z, Syed A, Ojha K, Bourne T. The conservative management of cervical ectopic pregnancies. Ultrasound Obstet Gynecol 2006;27:430-7.

11. Verma U, Goharkhay N. Conservative management of cervical ectopic pregnancy. Fertil Steril 2009;91:671-4.

12. Vela G, Tulandi T. Cervical pregnancy: the importance of early diagnosis and treatment. J Minim Invasive Gynecol 2007;14:481-4.

13. Maral İ, Sözen U, Balık E. Servikal Gebeliğin Konservatif Tedavisi (Olgu Sunumu). Turk Klin Jinekol Obst.1993;3:67-9.

14. Seçen IE, Keskin HL, Avşar AF. Servikal ektopik gebelik: Üç olgu sunumu. J Turk Soc Obstet Gynecol 2012;9:229-32.

15. Hirakawa M, Tajima T, Yoshimitsu K, Irie H, Ishigami K, Yahata H, et al. Uterine artery embolization along with the administration of methotrexate for cervical ectopic pregnancy: technical and clinical outcomes. AJR Am J Roentgenol 2009;192:1601-7.

16. Nakao Y, Yokoyama M, Iwasaka T. Uterine artery embolization followed by dilation and curettage for cervical pregnancy. Obstet Gynecol. 2008;111(2 Pt 2):505-7.

17. Samal SK, Rathod S. Cervical ectopic pregnancy. J Nat Sci Biol Med. 2015;6:257-60.

18. Alammari R, Thibodeau R, Harmanli O. Vaginal Hysterectomy for Treatment of Cervical Ectopic Pregnancy. Obstet Gynecol. 2017;129:63-5.

19. Papp Z, Tóth-Pál E, Papp C, Sziller I, Silhavy M, Gávai M, et al. Bilateral hypogastric artery ligation for control of pelvic hemorrhage, reduction of blood flow and preservation of reproductive potential. Experience with 117 cases. Orv Hetil 2005;146:1279-85. 